\title{
Death Of Child With Leukaemia Subjected To Traditional Uvulectomy
}

\author{
A Olaosun, K Ojemakinde, A Raji, T Adedeji, S Adebola
}

\author{
Citation \\ A Olaosun, K Ojemakinde, A Raji, T Adedeji, S Adebola. Death Of Child With Leukaemia Subjected To Traditional \\ Uvulectomy. The Internet Journal of Third World Medicine. 2006 Volume 4 Number 2.
}

DOI: $\underline{10.5580 / 9 \mathrm{e} 0}$

\begin{abstract}
A case is reported of a 5 year old girl who had uvulectomy done by traditional practitioners as treatment for sore throat. She was admitted 24 hours after the procedure due to epistaxis. At the time of admission the epistaxis had stopped but the pharynx was badly inflamed and she was found to be severely anemic. Unfortunately before anything could be done the patient expired. Autopsy however revealed that the child had Acute Leukemia The case is worthy of note since the practice of traditional uvulectomy is still common in many countries and also because sore throat, one of the commonest reasons for which it is performed can be due to serous life threatening conditions like Leukemia as well as to remind us that traditional Uvulectomy causes a lot of unnecessary morbidity and mortality and something must be done about it
\end{abstract}

\section{INTRODUCTION}

Traditional uvulectomy (removal of the uvula by traditional practitioners) is a very common practice in several subSaharan African countries, in Maghreb and in Israel $\left({ }_{5}, 9,{ }_{12}\right)$. It has also been reported in the Saudi Arabia $\left({ }_{2}\right)$

Many of the severe complications that often attend the procedure have been reported in literature. We here report a case in which death resulted after Traditional Uvulectomy was done for recurrent sore throat in a child who eventually turned out to have leukemia.

\section{CASE REPORT}

Miss A.A. a five year old girl was admitted in the Accidents $\&$ E on account of bleeding from both nostrils of a day's duration. Bleeding had been profuse and the mother could not estimated the blood loss. There was no preceding history of Trauma but had had traditional uvulectomy done about 32 hrs prior to presentation. The reason for the procedure was recurrent sore throat. Prior to the procedure she had had an episode which had been on for several days. There was associated fever, noisy breathing and mouth breathing. She had been taken to the local General hospital where she had been given some treatment. It was when there was no relief that she was taken to the Hausa section of town for the traditional uvulectomy.
Examination revealed a very restless child who was uncooperative and examination done by restraining her. She was fully conscious and alert, though moderately pale and dehydrated and febrile $\left(\mathrm{T}-38^{\circ} \mathrm{C}\right)$. There was tachycardia. Though there were crusts of blood around the nares and in both nostrils, there was no evidence of ongoing bleeding.

Oropharyngeal examination revealed an inflamed oropharynx with an inflamed and massively swollen uvula stump. Both tonsils were also inflammed

In the neck there were multiple tender small $(<2 \mathrm{~cm})$ submandibular lymph nodes but other aspects of the examination were normal.

An assessment of Acute Pharyngitis, Septicaemia, and Epistaxis (Probably secondary to Traditional Uvulectomy) was made. She was admitted and an urgent PCV was done. She was to be transfused if the Packed Cell Volume was less than $25 \%$. The PCV came back as $24 \%$ and blood was taken for grouping and crossmatching as well as a full blood count, serum electrolytes, urea and creatinine. Meanwhile, fluid resuscitation (Normal Saline) was commenced with the patient on urethral catheter. She was also placed on IV ceftriaxone $1 \mathrm{~g}$ daily and IV Metronidazole $250 \mathrm{mg}$ tds. She was placed on a red alert and the teatre was prepared to intervene should there be airway obstruction. 
Unfortunately, however before any of the above could be done, the patient suddenly had a tonic clonic seizure followed by gasping and all attempts to resuscitate failed.

Autopsy done on the next day revealed Hepatomegaphy, Speenomgaphy, Gastrointestinal haemorrhage in the Oesophagus, Lungs, Heart and intestines. Tissue Biopsy result came back as acute Leukamia

\section{DISCUSSION}

Although Uvulectomy is rarely done in otorhinolaryngological practice and is unusual for minor pharyngeal lesions $\left({ }_{3}\right)$, the procedure is commonplace as treatment for recurrent sore throat in traditional medical

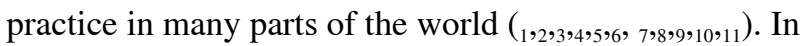
Nigeria though the 'surgeons' are usually of the Hausa tribe, the practice is widespread and the clientele includes people of other tribes irrespective of social status or education . It is a procedure in which traditional practitioners, usually barbers $\left({ }_{3}\right)$, amputate the uvula with non-sterilized sickleshaped knives without any form of anesthesia, after which they apply a mixture of herbs to the stump on the soft palate. Numerous severe complications have been found in association with the procedure $\left({ }_{12}\right)$. They include severe hemorrhage and anaemia $\left({ }_{9},{ }_{12}, 13,14,{ }_{15}\right)$, oropharyngeal infection $\left({ }_{13}, 15\right)$, cellulites of the neck $\left({ }_{15}\right)$, septicemia $\left({ }_{15}\right)$, peritonsillar and parapharyngeal abscesses $\left(_{15}\right)$, aspiration with consequent upper airway obstruction $\left({ }_{9}, 15\right)$ and lung diseases including abscesses $\left({ }_{16}\right)$, laryngocoele with pneumothorax $\left({ }_{15}\right)$, tetanus $\left({ }_{9},{ }_{17}\right)$, Infant and Child morbidity $\left({ }_{6}, 9,17\right)$ and even death $\left({ }_{17},{ }_{18}\right)$.

Even though this child was eventually diagnosed as having leukemia, there is no doubt that the stress, possible dissemination of the throat sepsis by the procedure and hemorrhage contributed to the final demise of the patient.

Traditional Uvulectomy is still common in many countries and probably the most common symptom for which it is done is sore throat, which in itself is a very common symptom. The fear in this case is that, as is the case in many developing countries, what we see in the hospitals is only the tip of the iceberg. What this means is that we are definitely missing some of the cases, the morbidities and the mortalities thus calling for increased vigilance.There is also a serious need for health education of the public concerning the to prevent the terrible complications of traditional uvulectomy.

In Nigeria, Infant mortality rate is still high. Preventable causes such as this must be addressed.

\section{CORRESPONDENCE TO}

Dr. .A. O. OLAOSUN Department of Otorhinolaryngology Ladoke Akintola University Teaching Hospital Osogbo, Nigeria Email: dayowse@yahoo.com Telephone: + 234 $803-3736113$

\section{References}

1. Manni, J. J. (1983). "[Uvulectomy in Dar es Salaam (Tanzania)]." Med Welt

34(19): 584-6.

2. Abdullah, M. A. (1993). "Traditional practices and other socio-cultural factors affecting the health of children in

Saudi Arabia." Ann Trop Paediatr

13(3): 227-32.

3. Ijaduola, G. T. (1981). "Uvulectomy in Nigeria." J

Laryngol Otol

95(11): 1127-33.

4. Ijaduola, G. T. (1982). "Hazards of traditional uvulectomy in Nigeria." East Afr Med J

59(11): 771-4.

5. Hartley, B. E. and J. Rowe-Jones (1994). "Uvulectomy to prevent throat infections." J Laryngol Otol

108(1): 65-6.

6. Oyelami, O. A. (1993). "Traditional uvulectomy among preschool children in the far north eastern Nigeria." J Trop

Pediatr

39(5): 314-5.

7. Schneider, P., E. Shewangizaw, et al. (1989).

"[Traditional medicine in Ethiopia in childhood diseases]."

Kinderarztl Prax

57(8): 393-9.

8. Dagnew, M. B. and M. Damena (1990). "Traditional child health practices in communities in north-west Ethiopia."

Trop Doct

20(1): 40-1.

9. Prual, A., Y. Gamatie, et al. (1994). "Traditional

uvulectomy in Niger: a public health problem?" Soc Sci Med 39(8): 1077-82.

10. Einterz, E. M., R. M. Einterz, et al. (1994). "Traditional uvulectomy in northern Cameroon." Lancet

343(8913): 1644

11. Manni, J. J. (1982). "[Uvulectomy: a surgical procedure within the traditional medicine of Tanzania]." Ned Tijdschr Geneeskd

126(37): 1678-81.

12. Nathan, H., I. Hershkovitz, et al. (1982). "Mutilation of the uvula among Bedouins of the South Sinai." Isr J Med Sci 18(7): 774-8

13. Adekeye, E. O., F. Kwamin, et al. (1984). "Serious complications associated with uvulectomy performed by a "native doctor"." Trop Doct

14(4): 160-1.

14. Asha Bai, P. V. (1985). "Uvulectomy." Lancet

1(8422): 225.

15. Olu Ibekwe, A. (1983). "Complications of the 'treatment' of tonsillar infection by traditional healers in Nigeria." J

Laryngol Otol

97(9): 845-9.

16. Haddock, D. R. and A. D. Chiduo (1965). "Uvulectomy in coastal Tanzania." Cent Afr J Med

11(11): 331-4.

17. Eregie, C. O. (1994). "Uvulectomy as an epidemiological factor in neonatal tetanus mortality:- observations from a 
cluster survey." West Afr J Med

13(1): 56-8.
18. Nalin, D. R. (1985). "Death of child submitted to uvulectomy for diarrhoea." Lancet 1(8429): 643. 


\section{Author Information}

\section{A. O. Olaosun, FWACS (Fellow, West African College of Surgeons)}

Department of Otorhinolaryngology, Ladoke Akintola University Teaching Hospital

K. O. Ojemakinde, FWACPLab Med (Fellow, West African College of Physicians (Laboratory Medicine)

Department of Morbid Anatomy, Ladoke Akintola University Teaching Hospital

\section{A. A. Raji, FMCPath(Fellow, Medical College of Pathologists, National Postgraduate Medical College of Nigeria)} Department of Haematology, Ladoke Akintola University Teaching Hospital

T. O. Adedeji, MBChB (Bachelor of Medicine, Bachelor of Surgery)

Department of Otorhinolaryngology, Ladoke Akintola University Teaching Hospital

S. O. Adebola, MBBS (Bachelor of Medicine, Bachelor of Surgery)

Department of Otorhinolaryngology, Ladoke Akintola University Teaching Hospital 